\title{
Effects of the histone deacetylase inhibitor valproic acid on the sensitivity of anaplastic thyroid cancer cell lines to imatinib
}

\author{
MARIA GRAZIELLA CATALANO ${ }^{1}$, MARIATERESA PUGLIESE ${ }^{1}$, ROBERTA POLI ${ }^{1}$, ORNELLA BOSCO ${ }^{1}$, \\ RAFFAELLO BERTIERI ${ }^{2}$, NICOLETTA FORTUNATI ${ }^{3}$ and GIUSEPPE BOCCUZZI ${ }^{1,3}$ \\ ${ }^{1}$ Department of Clinical Pathophysiology, University of Turin, Via Genova 3, 10126 Turin, \\ ${ }^{2}$ Medical Department, Novartis Farma, Largo Umberto Boccioni, 1, 21040 Origgio (Va), \\ ${ }^{3}$ Oncological Endocrinology, ASO San Giovanni Battista, Via Genova 3, 10126 Turin, Italy
}

Received September 18, 2008; Accepted November 7, 2008

DOI: $10.3892 /$ or_00000252

\begin{abstract}
New therapeutic approaches are mandatory for anaplastic thyroid cancer. We investigated the ability of a new combined treatment using valproic acid (VPA), the only clinically available histone deacetylase inhibitor, and the tyrosine-kinase inhibitor imatinib mesylate to control the cell growth of anaplastic thyroid cancer cell lines. We showed that treatment with imatinib alone is unable to affect the cell growth of anaplastic thyroid cancer cells, whereas in ARO cells, the combined treatment resulted in a cytostatic effect, with clinically achievable doses of imatinib and VPA. The effect is mediated by $\mathrm{G}_{1}$ growth arrest, acting through p21 expression and the impairment of AKT phosphorylation.
\end{abstract}

\section{Introduction}

Anaplastic thyroid cancer (ATC) is one of the most aggressive malignancies in humans. Multi-disciplinary treatments including radio- and chemotherapy poorly control the progression of this disease and patients rarely survive $>1$ year after initial diagnosis (1). Novel strategies to control this lethal malignancy are therefore mandatory $(2,3)$. Imatinib mesylate is a molecular target agent that suppresses signal transduction pathways mediated through c-Abl, c-kit, and platelet-derived growth factor receptors (PDGFRs) (4). Imatinib is already used to treat patients with chronic myeloid leukaemia (CML) over-expressing Bcr-Abl mutant proteins (5) and those with gastrointestinal stromal tumours (GIST) harboring active forms of c-kit somatic mutations (6). Moreover, preclinical studies suggested a potential antitumour activity of imatinib in other solid tumours, such as ovarian cancer (7), prostate cancer (8), neuroblastoma (9)

Correspondence to: Professor Giuseppe Boccuzzi, Department of Clinical Pathophysiology, Via Genova 3, 10126 Torino, Italy E-mail: giuseppe.boccuzzi@unito.it

Key words: anaplastic thyroid cancer, valproic acid, imatinib mesylate, cell cycle, AKT and osteosarcoma (10). Only a few reports on the effect of imatinib on ATC cells are currently available, with contradictory results (11-13). Podtchecko et al (11) demonstrated that imatinib is a potential anticancer drug against undifferentiated thyroid carcinoma. However, achieving the necessary doses of imatinib which would have cytotoxic effects on ATC cells in patients is difficult. Moreover, even if the doses were achieved by higher dosing, it would result in dose-limiting toxicity (12). Thus, imatinib mesylate monotherapy appears to be ineffective in suppressing human ATC cell growth in vitro.

Reinforcement of the killing activity of drugs targeting DNA $(2,14,15)$ and tubulin (3) has been reported for histone deacetylase inhibitors (HDIs), a potent class of antineoplastic agents. These drugs induce differentiation, growth arrest and apoptosis of transformed cells (16-18). Several HDIs such as SAHA (19), LAQ824 (20), MS-275 (21) and valproic acid (22) enhance imatinib-induced growth arrest and apoptosis in imatinib-sensitive and -resistant leukaemic cell lines.

We investigated the ability and underlying mechanisms of a new combined treatment using valproic acid (VPA), the only clinically available HDI, and imatinib mesylate to regulate the cell growth of ATC cell lines.

\section{Materials and methods}

Drugs, cell lines and culture conditions. Valproic acid was purchased from Sigma-Aldrich and imatinib mesylate was kindly provided by Novartis Pharma AG (Basel, Switzerland).

Anaplastic thyroid carcinoma cell lines (CAL-62 and 8305C) were purchased from the Deutche Sammlung von Mikroorganismen and Zellculturen (Braunschweig, Germany), while ARO cells were a kind gift from Professor Paola Cassoni (Pathology Service, Department of Oncology, University of Turin). CAL-62 cells were routinely maintained in DMEM-F12 (Invitrogen, Groningen, The Netherlands) supplemented with $10 \%$ heat-inactivated FCS (Euroclone, Wetherby, West York, UK). 8305C cells were maintained in Eagle's essential minimal medium (E-MEM) supplemented with $1 \%$ non-essential amino acids (Sigma) and $10 \%$ heat-inactivated FCS. The ARO cell line was maintained in RPMI-1640 (Sigma, St. Louis, MO, USA) supplemented with $10 \%$ heat-inactivated FCS. 
Table I. Primer sequences for real-time PCR.

Forward

Reverse

\begin{tabular}{lll}
\hline ABL & 5'-GCGTGAGAGTGAGAGCAGTCC-3' & 5'-TGGATAATGGAGCGTGGTGATGAG-3' \\
c-kit & 5'-TTCTCTGCGTTCTGCTCCTACTG-3' & 5'-GGATGGATGGTGGAGACGGTTC-3' \\
PDGFR- $\beta$ & 5'-AATCCACAGCCCGCAGCAG-3' & 5'-TAGTCCACCAGGTCTCCGTAGC-3' \\
AKT & 5'-GCAAGGGCACTTTCGGCAAG-3' & 5'-AGGCGGTCGTGGGTCTGG-3' \\
p21 & 5'-ACCTGTCACTGTCTTGTACCCTTG-3' & 5'-GGCGTTTGGAGTGTAGAAATCTG-3' \\
p27 & 5'-AGCAGACGCCCAAGAAGCC-3' & 5'-GGATGTCCATTCCATGAAGTCAGC-3' \\
ß-actin & 5'-GCGAGAAGATGACCCAGATC-3' & 5'-GGATAGCACAGCCTGGATAG-3' \\
ß2-microglobulin & 5'-AGATGAGTATGCCTGCCGTGTG-3' & 5'-TCAAACCTCCATGATGCTGCTTAC-3' \\
Ribosomal protein L13a & 5'-GCAAGCGGATGAACACCAACC-3' & 5'-TTGAGGGCAGCAGGAACCAC-3' \\
\hline
\end{tabular}

Cell viability and cytotoxicity. To assess the effect of VPA on imatinib antitumour activity, cells were seeded at $1 \times 10^{3} /$ well in 96-well plates (Corning, New York, NY, USA) in culture medium added with $10 \%$ heat-inactivated FCS. After $48 \mathrm{~h}$, cells were exposed to $0.7 \mathrm{mM}$ VPA for $24 \mathrm{~h}$ before the addition of imatinib (1-10 $\mu \mathrm{M})$. After a further 72-h incubation, cell viability was tested using the Cell Proliferation Reagent WST-1 (Roche Applied Science, Penzberg, Germany), following the manufacturer's instructions. Four replicate wells were used to determine each data point. Three response parameters were calculated for each cell line: the median growth inhibition $\left(\mathrm{GI}_{50}\right)$, total growth inhibition (TGI) and median lethal concentration $\left(\mathrm{LC}_{50}\right)$. $\mathrm{GI}_{50}$ defines the concentration of the compound that inhibits $50 \%$ net cell growth, the TGI value is the concentration leading to total inhibition and $\mathrm{LC}_{50}$ is the lethal dose of the drug for $50 \%$ net of cells. The dose of $0.7 \mathrm{mM}$ VPA has been selected because it corresponds to plasma levels in patients treated for epilepsy.

Concerning imatinib doses, the higher concentration used in our study $(10 \mu \mathrm{M})$ is just beyond the mean plasma concentration $(7.8 \mu \mathrm{M})$ reached in CML patients treated with $600 \mathrm{mg}$ of imatinib once daily in a phase II clinical study (23).

\section{Apoptosis detection}

Cell death detection ELISA. For apoptosis studies, $1 \times 10^{3}$ cells/well were seeded in 96-well plates and treated with VPA and imatinib (5 and $8 \mu \mathrm{M}$ ), using the same schedule as for the antitumour activity. After different treatments, apoptosis was evaluated using cell death detection ELISA Plus (Roche Applied Science) following the manufacturer's instructions. Apoptosis was expressed as an enrichment factor, and calculated as a fraction of the absorbance of treated cells versus untreated controls.

Caspase activity assay. Cells $\left(5 \times 10^{5}\right)$ were seeded in $75 \mathrm{~cm}^{2}$ flasks and exposed to VPA and imatinib as above. After drug treatments, caspase 3 was determined using a colorimetric assay kit (R\&D Systems Inc., Minneapolis, MN, USA). Briefly, cells were lysed and incubated with the colorimetric substrate DEVD-pNA for $2 \mathrm{~h}$ at $37^{\circ} \mathrm{C}$. After incubation, the chromophore was quantified spectrophotometrically at $405 \mathrm{~nm}$.

Cell cycle analysis. Cells were treated with $0.7 \mathrm{mM} \mathrm{VPA}$ for $24 \mathrm{~h}$, followed by treatment with 5 or $8 \mu \mathrm{M}$ imatinib for $48 \mathrm{~h}$.
After treatment, cells were collected, fixed in $70 \%$ ethanol for $30 \mathrm{~min}$ on ice and incubated in propidium iodide solution (20 $\mu \mathrm{g} / \mathrm{ml}$ propidium iodide and $0.2 \mathrm{mg} / \mathrm{ml}$ RNAseA in PBS) for $1 \mathrm{~h}$ at room temperature. The cell population was analyzed by flow cytometry.

\section{Gene expression evaluation with real-time PCR}

RNA extraction. Cells ( $2 \times 10^{5} /$ well) were seeded in 6-well plates and treated as described above. Total RNA was extracted using TRIzol reagent (Invitrogen Ltd., Paisley, UK). DNase was added to remove genomic DNA residuals.

cDNA synthesis and PCR amplification for Abl, c-kit, $P D G F R-\beta, A K T, p 21$ and $p 27$. Total RNA $(1 \mu \mathrm{g})$ was reversetranscribed with iScript cDNA synthesis kit (BioRad Laboratories, Inc.), following the manufacturer's protocol.

Primers were designed using Beacon Designer 5.0 software according to parameters outlined in the BioRad iCycler manual. Primer specificity was confirmed by BLAST analysis. The primer sequences are listed in Table I. Actin, ß2-microglobulin and ribosomal protein L13a were used as housekeeping genes.

Real-time PCR was performed using the BioRad iQ iCycler detection system (BioRad Laboratories, Inc.) with SYBR-Green as a fluorophore. The total reaction volume was $25 \mu 1$ and included 12.5 $\mu \mathrm{l}$ iQ SYBR-Green Supermix (BioRad Laboratories, Inc.), $1 \mu 1$ of $10 \mu \mathrm{M}$ primer and $5 \mu 1$ of previously reverse-transcribed cDNA template. Conditions of RT-PCR included denaturation at $95^{\circ} \mathrm{C}$ for $5 \mathrm{~min}$ and 40 cycles of amplification $\left(95^{\circ} \mathrm{C}\right.$ for $15 \mathrm{sec}$ and $60^{\circ} \mathrm{C}$ for $\left.30 \mathrm{sec}\right)$. A melt curve analysis was performed following every run to ensure a single product of amplification for every reaction. Reactions were carried out at least in triplicate for each sample. Relative expression levels were obtained using the GeneEx program (BioRad), after geometrical normalization against the three different housekeeping genes.

Western blot analysis. Cells $\left(1 \times 10^{6}\right)$ were seeded in $75 \mathrm{~cm}^{2}$ flasks and treated as described for cell cycle analysis. After treatment, the cells were lysed in RIPA buffer (PBS, pH 7.4, $1 \%$ Nonidet $\mathrm{P} 40,0.1 \%$ SDS and $0.5 \%$ sodium deoxycholate) added with $100 \mu \mathrm{g} / \mathrm{ml}$ PMSF, $30 \mu \mathrm{l} / \mathrm{ml}$ aprotinin, $100 \mathrm{mM}$ $\mathrm{NaVO}_{4}$ and 0.7 VPA when required to maintain acetylation. The cells were extracted at $4^{\circ} \mathrm{C}$ for $30 \mathrm{~min}$ and centrifuged at 
A

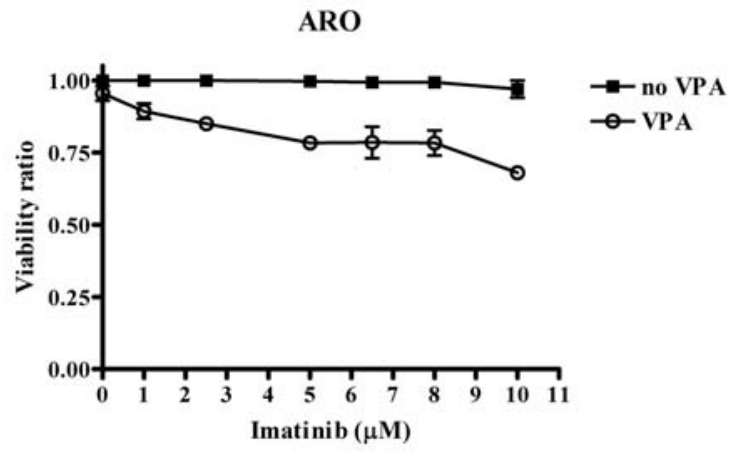

$\mathrm{B}$

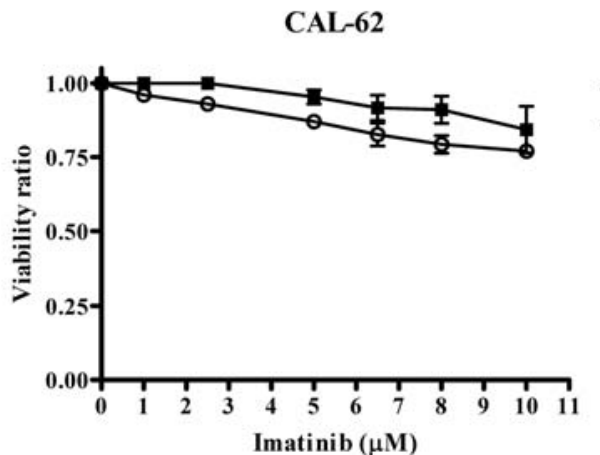

8305-C
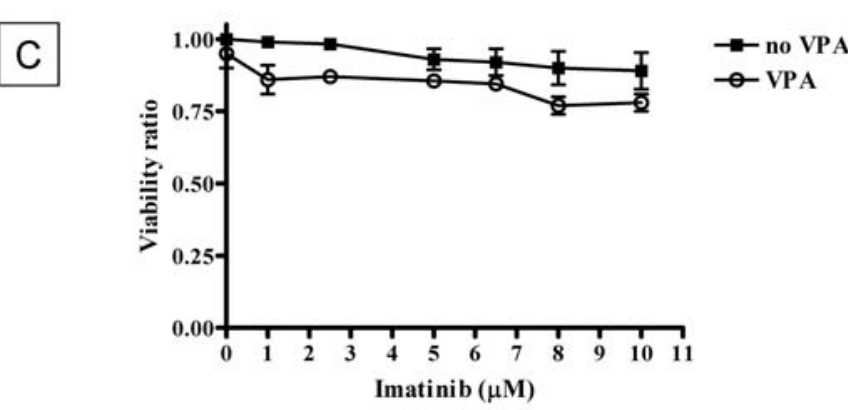

Figure 1. Sensitizing effect of VPA to imatinib in anaplastic thyroid cancer cells. (A) ARO, (B) CAL-62 and (C) 8305C cells were incubated for $24 \mathrm{~h}$ with $0.7 \mathrm{mM}$ VPA before the addition of imatinib (1-10 $\mu \mathrm{M})$. After a further 72-h incubation, cell viability was determined by the WST-1 method, and expressed as the ratio between treated cells and untreated controls (without imatinib or VPA).

$4^{\circ} \mathrm{C}$ for $20 \mathrm{~min}$ at $15,000 \mathrm{x} \mathrm{g}$. Aliquots of $50 \mu \mathrm{g}$ of total protein were loaded to each lane of $12 \%$ (for p 21 and actin) or $8 \%$ (for Akt and P-Akt) SDS-polyacrylamide gels and proteins were electrically transferred to PVDF membranes. Membranes were probed with the primary antibodies of polyclonal antip21 (sc-397, 1:200 dilution, Santa Cruz Biotechnology Inc.,
Santa Cruz, CA, USA); monoclonal anti-actin (clone AC-40, 1:1000 dilution, Sigma); polyclonal anti-phospo-Akt (Ser473; 1:1000 dilution, Cell Signaling Technology Inc., Danvers, MA, USA) and polyclonal anti-Akt (1:2000 dilution, Cell Signaling Technology Inc.). The secondary antibodies were diluted at 1:10000. Western blot analysis against actin was used to control protein loading.

Proteins were detected with the Pierce Super Signal chemiluminescent substrate following the manufacturer's instructions. Bands were photographed using the PC software 1D Kodak Digital Science.

Statistical analysis. Data are expressed throughout as means \pm SEM, calculated from at least three different experiments. In viability experiments, the statistical comparison between cells treated with VPA plus imatinib, and VPA alone was performed with the Mann-Whitney U test. A comparison between the groups was performed with analysis of variance (one-way ANOVA) and the threshold of significance was calculated with the Bonferroni test. Statistical significance was set at $\mathrm{P}<0.05$.

\section{Results}

Effect of VPA and imatinib on cell viability. As shown in Fig. 1 and Table II, treatment with imatinib alone up to the dose of $10 \mu \mathrm{M}$ had no effect on the growth of ATC cell lines (CAL-62, ARO and 8305C). Pre-treatment with $0.7 \mathrm{mM} \mathrm{VPA}$ significantly increased the imatinib effect in ARO cells $(\mathrm{P}<0.05)$, whereas no potentiation was observed in CAL-62 and $8305 \mathrm{C}$ cells.

Effect of VPA and imatinib on cell cycle progression and apoptosis induction. To get insight into the mechanisms underlying the antitumour effect of the combined treatment with VPA and imatinib in ARO cells, we evaluated the effect of the two drugs on cell cycle progression and apoptosis induction. As shown in Table III, neither VPA nor imatinib (up to the dose of $8 \mu \mathrm{M}$ ) had any effect on cell cycle progression (Table III) and apoptosis induction (Fig. 2) of ATC cells, when used alone. Pre-treatment with VPA resulted in $\mathrm{G}_{1}$ cell cycle arrest in ARO cells, a total of $58.8 \%$ of VPA $+5 \mu \mathrm{M}$ imatinib-treated cells were in $\mathrm{G}_{1}$ compared with $48.1 \%$ of cells cultured with $5 \mu \mathrm{M}$ imatinib alone $(\mathrm{p}<0.01)$ and a total of $66.0 \%$ of VPA $+8 \mu \mathrm{M}$ imatinibtreated cells were in $\mathrm{G}_{1}$ compared with $58.8 \%$ of cells cultured with $8 \mu \mathrm{M}$ imatinib alone $(\mathrm{p}<0.001)$.

After combined treatment, we observed no apoptosis induction at any concentration used, nor were nucloeosome

Table II. $\mathrm{GI}_{50}$, TGI and $\mathrm{LC}_{50}$ for imatinib $(\mu \mathrm{M})$ after treatment with imatinib alone or combined with VPA.

\begin{tabular}{|c|c|c|c|c|c|c|}
\hline & \multicolumn{2}{|c|}{ CAL-62 } & \multicolumn{2}{|c|}{ ARO } & \multicolumn{2}{|c|}{$8305 \mathrm{C}$} \\
\hline & Imatinib & Imatinib + VPA & Imatinib & Imatinib + VPA & Imatinib & Imatinib + VPA \\
\hline $\mathrm{GI}_{50}$ & $\geq 10$ & $\geq 10$ & $\geq 10$ & 5 & $\geq 10$ & $\geq 10$ \\
\hline TGI & $\geq 10$ & $\geq 10$ & $\geq 10$ & $\geq 10$ & $\geq 10$ & $\geq 10$ \\
\hline $\mathrm{LC}_{50}$ & $\geq 10$ & $\geq 10$ & $\geq 10$ & $\geq 10$ & $\geq 10$ & $\geq 10$ \\
\hline
\end{tabular}


Table III. Effect of VPA and imatinib on cell cycle progression of ATC cell lines.

\begin{tabular}{|c|c|c|c|}
\hline & $\mathrm{G}_{1}$ & $\mathrm{~S}$ & $\mathrm{G}_{2} / \mathrm{M}$ \\
\hline \multicolumn{4}{|l|}{ ARO } \\
\hline Basal & $52.8 \pm 2.3$ & $38.1 \pm 1.5$ & $9.2 \pm 0.9$ \\
\hline 0.7 mM VPA & $49.7 \pm 2.2$ & $40.3 \pm 2$ & $10.0 \pm 0.3$ \\
\hline $5 \mu \mathrm{M}$ imatinib & $48.1 \pm 1.6$ & $43.6 \pm 1.3$ & $8.3 \pm 0.4$ \\
\hline $5 \mu \mathrm{M}$ imatinib $+\mathrm{VPA}$ & $58.8 \pm 1.3(* *)$ & $36.3 \pm 1.4$ & $5.0 \pm 0.2$ \\
\hline $8 \mu \mathrm{M}$ imatinib & $50.5 \pm 1.5$ & $43.4 \pm 1.7$ & $6.2 \pm 0.5$ \\
\hline $8 \mu \mathrm{M}$ imatinib + VPA & $66.0 \pm 1.0(* * *)$ & $30.8 \pm 1.4$ & $3.2 \pm 0.5$ \\
\hline \multicolumn{4}{|l|}{ CAL-62 } \\
\hline Basal & $45.8 \pm 0.9$ & $24.3 \pm 4.2$ & $29.9 \pm 5.1$ \\
\hline 0.7 mM VPA & $45.5 \pm 0.5$ & $24.3 \pm 5.1$ & $30.2 \pm 5.6$ \\
\hline $5 \mu \mathrm{M}$ imatinib & $47.2 \pm 0.4$ & $24.1 \pm 4.5$ & $29.6 \pm 5.0$ \\
\hline $5 \mu \mathrm{M}$ imatinib $+\mathrm{VPA}$ & $46.4 \pm 2.2$ & $23.1 \pm 4.6$ & $29.4 \pm 6.8$ \\
\hline $8 \mu \mathrm{M}$ imatinib & $45.5 \pm 4.2$ & $24.8 \pm 3.5$ & $29.6 \pm 7.8$ \\
\hline $8 \mu \mathrm{M}$ imatinib + VPA & $48.6 \pm 0.4$ & $23.4 \pm 3.1$ & $24.8 \pm 9.9$ \\
\hline \multicolumn{4}{|l|}{$8305 \mathrm{C}$} \\
\hline Basal & $46.1 \pm 4$ & $44.0 \pm 2.7$ & $9.8 \pm 1.5$ \\
\hline $0.7 \mathrm{mM}$ VPA & $42.3 \pm 1.5$ & $45.6 \pm 1.7$ & $12.0 \pm 0.9$ \\
\hline $5 \mu \mathrm{M}$ imatinib & $44.9 \pm 6$ & $46.2 \pm 3.5$ & $8.9 \pm 2.5$ \\
\hline $5 \mu \mathrm{M}$ imatinib + VPA & $44.0 \pm 2.3$ & $45.7 \pm 1.1$ & $10.3 \pm 1.2$ \\
\hline $8 \mu \mathrm{M}$ imatinib & $45.9 \pm 1.7$ & $44.6 \pm 1.0$ & $9.6 \pm 0.7$ \\
\hline $8 \mu \mathrm{M}$ imatinib + VPA & $46.4 \pm 1.0$ & $42.2 \pm 1.7$ & $11.3 \pm 1.0$ \\
\hline
\end{tabular}

$\mathrm{A}$

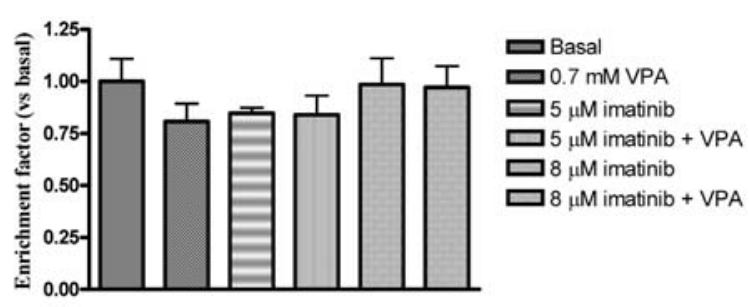

B

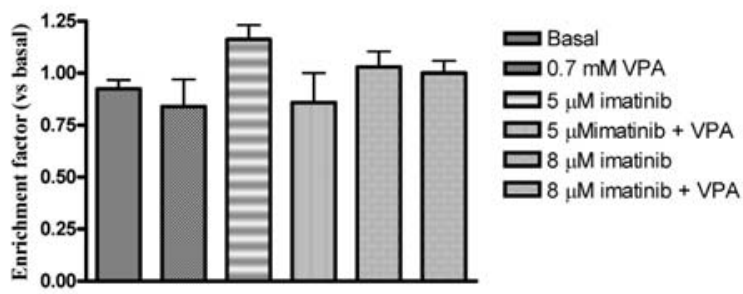

$\mathrm{C}$

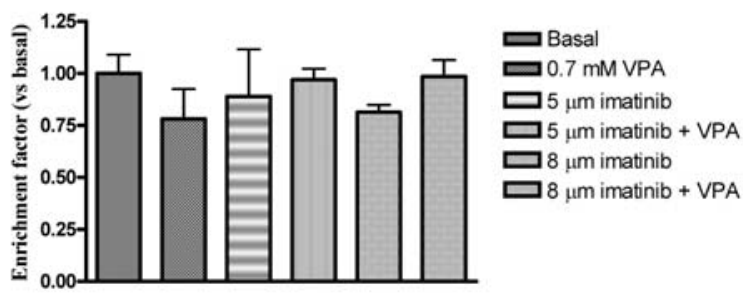

Figure 2. Effect of VPA and imatinib on apoptosis induction. ELISA detection of DNA-histone complexes. (A) ARO, (B) CAL-62 and (C) 8305C were treated with VPA $(0.7 \mathrm{mM})$ for $24 \mathrm{~h}$, followed by combined treatment with VPA and imatinib (5 and $8 \mu \mathrm{M}$ ) for a further $72 \mathrm{~h}$. The enrichment factor was calculated as the ratio between the absorbance measurements of treated cells and the basal value (exposed to neither VPA nor imatinib).

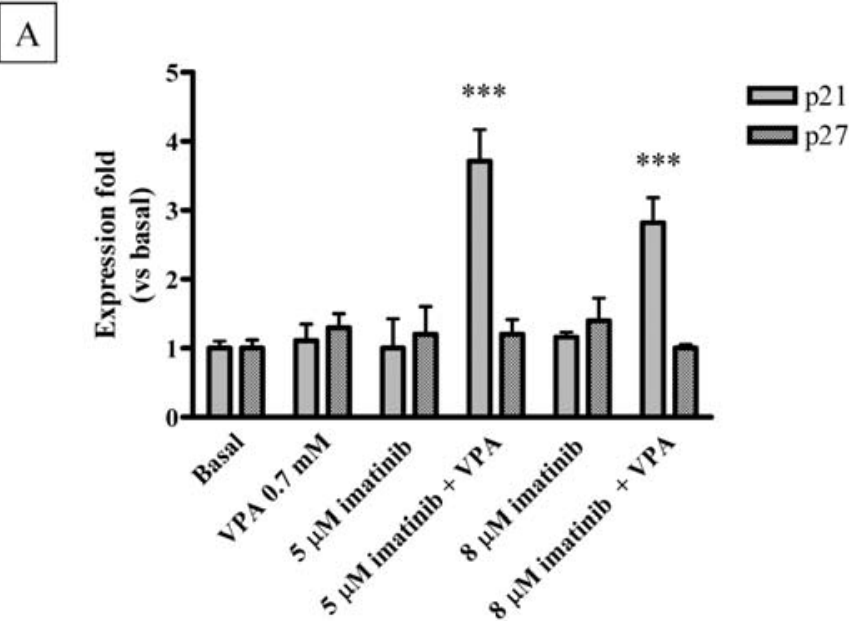

B

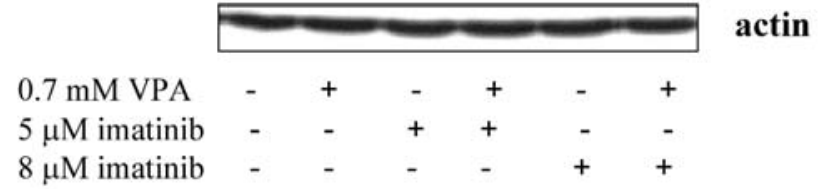

Figure 3. Effect of VPA and imatinib on the expression of p21 and p27. (A) mRNA expression changes of p 21 and p 27 in ARO cells after VPA and imatinib treatment. mRNA levels were determined with real-time PCR and normalized against actin, B2-microglobulin and protein L13a. Results are expressed as fold induction compared to untreated cells (basal). Significance vs basal, ${ }^{* * *} \mathrm{P}<0.001$. (B) $\mathrm{p} 21$ protein expression assessed by Western blot analysis with an anti-p21 antibody. Equal loading and transfer were verified by reprobing the membranes with an anti-actin antibody. 


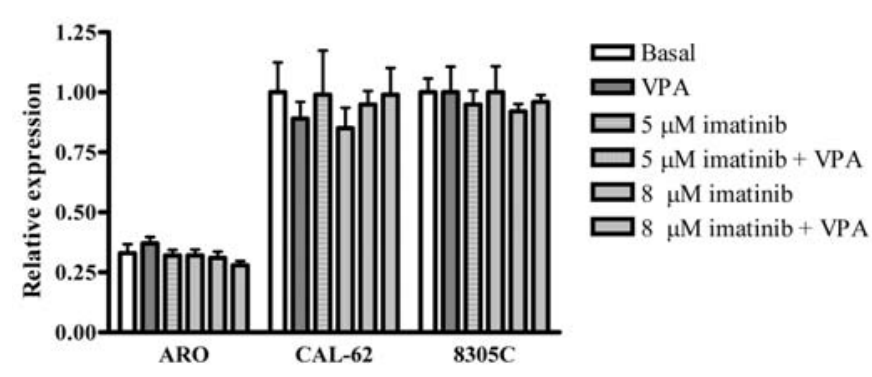

Figure 4. Effect of VPA and imatinib on the expression of Abl mRNA levels for c-Abl were determined with real-time PCR and normalized against actin B2-microglobulin and protein L13a. Results are expressed as fold induction compared to the higher mRNA expression level (CAL-62 cells exposed to neither VPA nor imatinib).

formation (Fig. 2) and caspase activation (data not shown) detected.

Effect of VPA and imatinib on p21 and p27 gene expression. To clarify the mechanism of VPA plus imatinib-induced $G_{1}$ cell cycle arrest in ARO cells, we examined the effect of the drugs on p21 and p27 gene expression involved in cell cycle control. p21 was up-regulated at the mRNA (Fig. 3A) and protein levels (Fig. 3B). Conversely, the mRNA expression of p27 was not changed upon treatment (Fig. 3A).

Effect of VPA and imatinib on the expression of $c$-Abl, c-kit, $P D G F R$ and $A K T$. Neither c-kit nor PDGFR were expressed in any of the cells (data not shown). c-Abl mRNA expression was observed in the ATC cell lines used for the study. Notably, in ARO cells the expression was only one third versus CAL-62 and $8305 \mathrm{C}$ cells. VPA plus imatinib treatment had no effect on the modulation of the gene expression (Fig. 4). Regarding AKT expression in ARO cells, drug treatments determined the inhibition of AKT phosphorylation, without any effect on the amount of total AKT (Fig. 5B) and on the mRNA expression level (Fig. 5A). No modulation of AKT expression and phosphorylation was observed in either CAL-62 or 8305C cells (data not shown).

\section{Discussion}

In the present study, we showed that treatment with imatinib alone is unable to affect the cell growth of anaplastic thyroid cancer cells, which is in line with previous data by Dziba et al (12). Other authors (11) have previously reported that only cell lines harbouring mutated p53 are sensitive to the drug. However, although the cell lines used in this study are p53mutated, they are resistant to imatinib when used alone up to the dose of $10 \mu \mathrm{M}$.

We demonstrated that a combined treatment of valproic acid and imatinib at concentrations clinically achievable for the two drugs, affects cell viability of the ARO cells, where a cytostatic effect is observed. The underlying mechanism is cell cycle arrest in $G_{1}$, whereas no apoptosis induction is observable. Cell cycle arrest is the result of the activation of
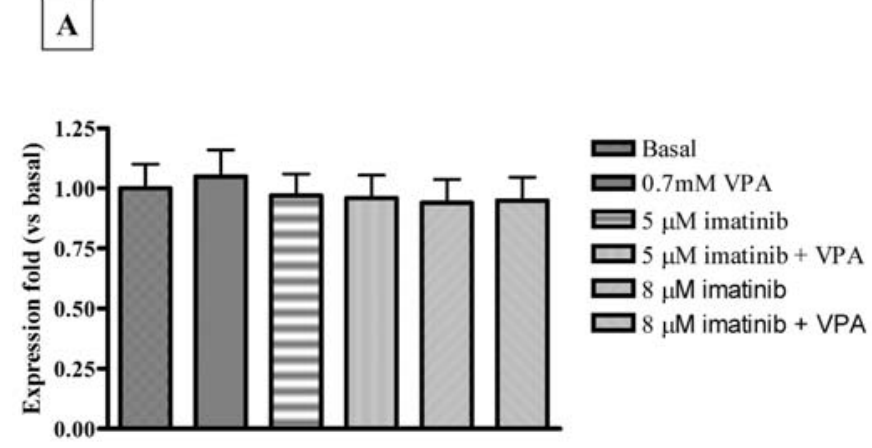

B

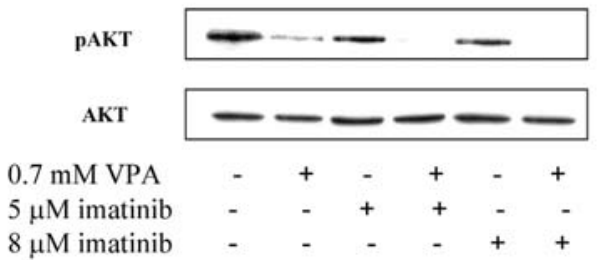

Figure 5. Effect of VPA and imatinib on AKT expression. (A) mRNA expression changes of AKT in ARO cells after VPA and imatinib treatment. mRNA levels were determined with real-time PCR and normalized against actin, B2-microglobulin and protein L13a. Results are expressed as fold induction compared to the untreated control group. Phosphorylated AKT protein was analyzed by Western blot analyis. pAKT levels were determined using an antibody against phosporylated AKT. Equal loading and transfer were verified by reprobing the membranes with an anti-AKT antibody.

p21 expression. HDIs induce cell-cycle arrest at $\mathrm{G}_{1} / \mathrm{S}$ (24) and this is most often associated with the p53-independent induction of CDKN1A, encoding p21. We demonstrated elsewhere (25) that VPA is able to induce p21 expression in poorly differentiated thyroid cancer cell lines, but no induction was observed when the drug was administered alone in anaplastic thyroid cancer cells.

The tyrosine kinase inhibitor imatinib selectively suppresses the activity of Abl, PDGFR and c-kit. In our cell lines, PDGFR and c-kit are not expressed and neither the drugs used alone nor the combined treatment are able to induce their expression. In contrast, RT-PCR revealed the presence of c-Abl mRNA in the cell lines we used. Abl affects cell proliferation phosphorylating many targets, including AKT (26). AKT regulates the process of cell survival by multiple substrates including cyclin D, Myc, p27 and p21 (27). In detail, AKT phosphorylates the cell cycle inhibitor p21 at two different residues, resulting in the cytoplasmatic localization of p21 and consequent promotion of the cell cycle (28). We showed that treatment with imatinib and valproic acid inhibits AKT phosphorylation. The question remains as to why valproic acid potentiates the action of imatinib only in ARO cells that express a lower level of Abl. Abl expression in ARO cells is one third lower than in CAL-62 and 8305C cells. VPA (22) as well as other HDIs, such as SAHA (19) and, more recently pivanex (29), have 
been reported to decrease the mRNA and protein levels of Bcr-Abl in myeloid leukaemia cells, enhancing imatinibinduced growth arrest. However, to our knowledge, the different treatments are not able to modify the expression of $\mathrm{Abl}$ in any of the cell lines. We suggest that valproic acid acts downstream of Abl expression, directly working against the phosphorylation of AKT induced by Abl. The lack of effects on the other cell lines may be dependent, at least partially, on the overexpression of Abl. In this case, the phosphorylating activity of Abl on AKT may overwhelm the inhibitory effect of the combined treatment.

Therefore, cell cycle arrest observed in ARO cells after treatment with imatinib and valproic acid is the result of the induction of p21 expression and inhibition of AKT phosphorylation. p21 is a well-known cell cycle inihibitor and AKT phosphorylation in turn regulates the $G_{1} / S$ transition by controlling the cell cycle inhibitor $\mathrm{p} 21$ at the post-translational level. AKT phosphorylates p21 at the residues Thr145 and Ser146. Thr145 residue phosphorylation results in the cytoplasmatic localization of $\mathrm{p} 21$ promoting the cell cycle, whereas Ser146 site phosphorylation enhances the stability of the protein and increases the assembly of the cyclin D-CDK4 transition complex.

VPA was shown to able to interfere with the AKT pathway, together with its ability to potentiate the activity of other anti-neoplastic agents with different mechanisms $(2,3)$ which defines the multifaceted activities of this sole clinically available HDI.

In conclusion, although a phase II clinical trial (Clinical Trials.gov Identifier: NCT00115739) using imatinib for the treatment of anaplastic thyroid cancer continues, the data from our investigations appear to discourage the monotherapeutic use of imatinib in this type of tumour. A combined treatment with imatinib and an HDI inhibitor such as valproic acid may be more effective. However, such treatment should be assessed in each case, as we observed the anti-tumour activity in only a single cell line.

\section{Acknowledgements}

This study was supported by the Special Project 'Oncology', Compagnia San Paolo, Turin, by MIUR and by Regione Piemonte.

\section{References}

1. Brignardello E, Gallo M, Baldi I, Palestini N, Piovesan A, Grossi E, Ciccone G and Boccuzzi G: Anaplastic thyroid carcinoma: clinical outcome of 30 consecutive patients referred to a single insti-tution in the past 5 years. Eur J Endocrinol 156: 425-430, 2007.

2. Catalano MG, Fortunati N, Pugliese M, Poli R, Bosco O, Mastrocola R, Aragno M and Boccuzzi G: Valproic acid, a histone deacetylase inhibitor, enhances sensitivity to doxorubicin in anaplastic thyroid cancer cells. J Endocrinol 191: 465-472, 2006.

3. Catalano MG, Poli R, Pugliese M, Fortunati N and Boccuzzi G: Valproic acid enhances tubulin acetylation and apoptotic activity of paclitaxel on anaplastic thyroid cancer cell lines. Endocr Relat Cancer 14: 839-845, 2007.

4. Buchdunger E, O'Reilly T and Wood J: Pharmacology of imatinib (STI571). Eur J Cancer 38: S28-S36, 2002.

5. Deininger M, Buchdunger E and Druker BJ: The development of imatinib as a therapeutic agent for chronic myeloid leukaemia. Blood 105: 2640-2653, 2005.
6. Dagher R, Cohen M, Williams G, Rothmann M, Gobburu J, Robbie G, Rahman A, Chen G, Staten A, Griebel D and Pazdur R: Approval summary: imatinib mesylate in the treatment of metastatic and/or unresectable malignant gastrointestinal stromal tumors. Clin Cancer Res 8: 3034-3038, 2002.

7. Matei D, Chang DD and Jeng MH: Imatinib mesylate (Gleevec) inhibits ovarian cancer cell growth through a mechanism dependent on platelet-derived growth factor receptor alpha and Akt inactivation. Clin Cancer Res 10: 681-690, 2004.

8. George DJ: Receptor tyrosine kinases as rational targets for prostate cancer treatment: platelet-derived growth factor receptor and imatinib mesylate. Urology 60: 115-121, 2002

9. Beppu K, Jaboine J, Merchant MS, Mackall CL and Thiele CJ: Effect of imatinib mesylate on neuroblastoma tumorigenesis and vascular endothelial growth factor expression. J Natl Cancer Inst 96: 46-55, 2004

10. Matsuyama S, Iwadate M, Kondo M, Saitoh M, Hanyu A, Shimizu K, Aburatani H, Mishima HK, Imamura T, Miyazono K and Miyazawa K: SB-431542 and gleevec inhibit transforming growth factor-beta-induced proliferation of human osteosarcoma cells. Cancer Res 63: 7791-7798, 2003.

11. Podtcheko A, Ohtsuru A, Tsuda S, Namba H, Saenko V, Nakashima M, Mitsutake N, Kanda S, Kurebayashi J and Yamashita S: The selective tyrosine kinase inhibitor, STI571, inhibits growth of anaplastic thyroid cancer cells. J Clin Endocrinol Metab 88: 1889-1896, 2003.

12. Dziba JM and Ain KB: Imatinib mesylate (gleevec; STI571) monotherapy is ineffective in suppressing human anaplastic thyroid carcinoma cell growth in vitro. J Clin Endocrinol Metab 89: 2127-2135, 2004

13. Kurebayashi J, Okubo S, Yamamoto Y, Ikeda M, Tanaka K, Otsuki T and Sonoo H: Additive antitumor effects of gefitinib and imatinib on anaplastic thyroid cancer cells. Cancer Chemother Pharmacol 58: 460-470, 2006.

14. Marchion DC, Bicaku E, Daud AI, Richon V, Sullivan DM and Munster PN: Sequence-specific potentiation of topoisomerase II inhibitors by the histone deacetylase inhibitor suberoylanilide hydroxamic acid. J Cell Biochem 92: 223-237, 2004.

15. Marchion DC, Bicaku E, Daud AI, Sullivan DM and Munster PN: Valproic acid alters chromatin structure by regulation of chromatin modulation proteins. Cancer Res 65: 3815-3822, 2005.

16. Marks PA, Richon VM, Breslow R and Rifkind RA: Histone deacetylase inhibitors as new cancer drugs. Curr Opin Oncol 13: 477-483, 2001.

17. Vigushin DM and Coombes RC: Histone deacetylase inhibitors in cancer treatment. Anticancer Drugs 12: 1-13, 2002.

18. Rosato RR and Grant S: Histone deacetylase inhibitors in cancer therapy. Cancer Biol Ther 2: 30-37, 2003

19. Nimmanapalli R, Fuino L, Stobaugh C, Richon V and Bhalla K: Cotreatment with the histone deacetylase inhibitor suberoylanilide hydroxamic acid (SAHA) enhances imatinib-induced apoptosis of Bcr-Abl-positive human acute leukemia cells. Blood 101: 3236-3239, 2003.

20. Nimmanapalli R, Fuino L, Bali P, Gasparetto M, Glozak M, Tao J, Moscinski L, Smith C, Wu J, Jove R, Atadja P and Bhalla K: Histone deacetylase inhibitor LAQ824 both lowers expression and promotes proteasomal degradation of $\mathrm{Bcr}-\mathrm{Abl}$ and induces apoptosis of imatinib mesylate-sensitive or -refractory chronic myelogenous leukemia-blast crisis cells. Cancer Res 63: 5126-5135, 2003.

21. Rosato RR, Almenara JA and Grant S: The histone deacetylase inhibitor MS-275 promotes differentiation or apoptosis in human leukemia cells through a process regulated by generation of reactive oxygen species and induction of p21CIP1/WAF1. Cancer Res 63: 3637-3645, 2003.

22. Morotti A, Cilloni D, Messa F, Arruga F, Defilippi I, Carturan S, Catalano R, Rosso V, Chiarenza A, Pilatrino C, Guerrasio A, Taulli R, Bracco E, Pautasso M, Baraban D, Gottardi E and Saglio G: Valproate enhances imatinib-induced growth arrest and apoptosis in chronic myeloid leukemia cells. Cancer 106: 1188-1196, 2006.

23. Mauro MJ and Druker BJ: STI571: targeting BCR-ABL as therapy for CML. Oncologist 6: 233-238, 2001.

24. Bolden JE, Peart MJ and Johnstone RW: Anticancer activities of histone deacetylase inhibitors. Nat Rev Drug Discov 5: 769-784, 2006.

25. Catalano MG, Fortunati N, Pugliese M, Costantino L, Poli R, Bosco O and Boccuzzi G: Valproic acid induces apoptosis and cell cycle arrest in poorly differentiated thyroid cancer cells. J Clin Endocrinol Metab 90: 1383-1389, 2005. 
26. Kharas MG and Fruman DA: ABL oncogenes and phosphoinositide 3-kinase: mechanism of activation and downstream effectors. Cancer Res 65: 2047-2053, 2005.

27. Maddika S, Ande SR, Panigrahi S, Paranjothy T, Weglarczyk K, Zuse A, Eshraghi M, Manda KD, Wiechec E and Los M: Cell survival, cell death and cell cycle pathways are interconnected: implications for cancer therapy. Drug Resist Updat 10: 13-29, 2007

28. Zhou BP, Liao Y, Xia W, Spohn B, Lee MH and Hung MC: Cytoplasmic localization of p21Cip1/WAF1 by Akt-induced phosphorylation in HER-2/neu-overexpressing cells. Nat Cell Biol 3: 245-252, 2001
29. Rabizadeh E, Merkin V, Belyaeva I, Shaklai M and Zimra Y: Pivanex, a histone deacetylase inhibitor, induces changes in BCR-ABL expression and when combined with STI571, acts synergistically in a chronic myelocytic leukemia cell line. Leuk Res 31: 1115-1123, 2007. 